\title{
СТРАТЕГІЯ РОЗВИТКУ РЕГІОНІВ В УМОВАХ ДИВЕРСИФІКАЦІЇ ЕКОНОМІКИ
}

\begin{abstract}
Мета. Обгрунтування теоретико-методичних засад та практичних рекомендачій щуодо визначення основних напрямів стратегії розвитку регіонів в умовах диверсифікаиії галузевого профілю економіки.

Методика. Теоретичне і практичне дослідження питань диверсифікації здійснено на основі узагальнення, аналізу $і$ синтезу. Для визначення галузевого профілю економіки Донецького регіону використано метод структурно логічного аналізу. Встановлення міжрегіональних розбіжностей здійснено за допомогою статистичного методу та методу формалізачіï.
\end{abstract}

Результати. Акцентовано увагу, щуо найбільи успішною стратегією є стратегія диверсифікації, в результаті чого досягається розосередження ризиків циклічності розвитку регіональної економічної системи, пов 'язаних з кон'юнктурою, специфічними ресурсами, геополітичними, інфраструктурними умовами функціонування соціально-економічної системи регіону. Обгрунтовано, щчо диверсифікована економіка має додаткові можливості для свого розвитку $і$ підвищення ефективності виробництва. Проаналізовано галузевий профіль економіки Донецького регіону та виявлено проблеми, пов'язані з моно функціональністю міст. Встановлено наявність глибоких міжрегіональних розбіжностей за показником валової доданої вартості, які знаходяться в зоні реальної небезпеки. За результатами дослідження обтрунтовано, щцо важливим напрямом економічного розвитку регіону має стати саме стратегія диверсифікації иляхом інтеграції $і$ конвергенції. Особливості диверсифікації залежатимуть від конкретних умов господарювання, проте, акцентовано, цчо більиу увагу варто приділити розвитку інноваційних галузей економіки.

Наукова новизна. Поглиблення теоретичних засад, науково-методичних підходів та практичного інструментарію щуодо визначення основних напрямів стратегії розвитку регіонів в умовах диверсифікації галузевого профілю економіки в умовах глибоких міжрегіональних розбіжностей.

Практична значимість. Посилення ролі інших галузей, крім тієї, яка є основною для конкретного регіону, $і$ зменшення залежності економіки міста від функціонування містоутворюючих підприємств, щзо створить підірунтя для подальшого сочіально-економічного благополуччя таких територій.

Ключові слова: регіон, стратегія розвитку, диверсифікація економіки, мономісто, монофункціональність, регіональні розбіжності, концентрація, інтеграџія, конвергенція

Вступ. На сучасному етапі на розвиток регіональної економіки значний вплив чинять інтеграційні і глобалізаційні процеси. У зв'язку 3 цим в регіональній структурі господарювання формуються нові сфери і застосовуються принципово нові методи ведення бізнесу. Регіональний розвиток відбувається на тлі подолання чинників, що стримують стійке економічне зростання. Більшість проблем регіональної економіки пов'язано 3 явним переважанням в її структурі частки сировинних галузей, недостатнім інвестуванням, низькою якістю існуючих механізмів підвищення регіональної конкурентоспроможності, наявністю глибоких міжрегіональних розбіжностей, а також великою кількістю мономіст, більшість яких характеризуються низьким рівнем функціональності.

Досвід успішних в економічному плані регіонів та регіональних комплексів свідчить, що для виходу 3 кризи можна використовувати різноманітні стратегії. Головною особливістю успішних стратегій $€$ те, що вони повинні відповідати специфіці діяльності господарства регіону, умовам ефективного використання виробничо-економічного потенціалу, вимогам збереження і відтворення на більш високому рівні економічних пропорцій.

Однією 3 таких успішних стратегій $\epsilon$ стратегія диверсифікації. Під терміном «диверсифікація економіки регіону» розуміється розосередження ризиків циклічності розвитку регіональної економічної системи, пов'язаних 3 кон'юнктурою, специфічними ресурсами, геополітичними, інфраструктурними умовами функціонування соціально-економічної системи регіону $[1$, c. 18].

3 метою подолання зазначених вище проблем пріоритетною стратегією регіонального розвитку може стати прискорена диверсифікація економіки.

Проте, важливо розуміти, що кардинально змінити структуру економіки миттєво неможливо в силу того, що в певних регіонах занадто велику частку займають вугільна, металургійна, коксохімічна, лісова галузі промисловості, які також складають основу сукупного обсягу експорту країни. Тому диверсифікацію регіональної економіки представляється доцільним проводити в поступово, уникаючи негативних наслідків 3 
боку соціальної сфери.

Аналіз останніх досліджень i публікацій. Ключові аспекти диверсифікації економіки висвітлені у роботах зарубіжних вчених.

Теоретичне i практичне дослідження питань диверсифікації на рівні підприємств умовно починається 3 праць К. Ендрюса [2], М. Горта [3], Е. Есінари [4] і С. Беррі [5]. Так, Ендрюс під диверсифікацією розуміє зміни, а у загальнішому вигляді розширення номенклатури товарів, вироблених окремими підприємствами і об'єднаннями [2, с. 135]. Горт під диверсифікацією розуміє одночасне обслуговування компанією кількох ринків [3, с. 228]. Беррі вказує на диверсифікацію в разі зростання кількості галузей, в яких функціонує компанія [4, с. 380]. Принципово інше визначення першим пропонує Есінара, вказуючи на зв'язок диверсифікації зі ступенем ризику як стратегії зниження ризику ринкової діяльності в несприятливих умовах i підвищення ступеня фінансової стійкості компанії [5, с. 27].

Внаслідок становлення теорії стратегічного управління формується уявлення про диверсифікацію як основу стратегії розвитку компанії, що знаходить своє відображення в дослідженнях Р. Рамелта [6], I. Ансоффа [7], Ф. Котлера [8], М. Портера [9], А.А. Томпсона і А.Дж. Стрікленд [10]. Так, Рамелт досліджує різноманітні форми диверсифікації i здійснює їх кількісну оцінку [6]. Ансофф відзначає, що диверсифікація - це перерозподіл ресурсів конкретного підприємства в інші сфери діяльності [7]. Котлер вважає диверсифікацію саме тією стратегією, що відкриває колосальні можливості для зростання підприємств за межами галузі, виділяючи при цьому концентричну, горизонтальну і конгломератну диверсифікацію [8]. Портер під диверсифікацією економічної діяльності розуміє розширення активності великих фірм, об'єднань, підприємств і цілих галузей за рамки основного бізнесу, при цьому виділяе виробництво товарів i послуг, що мають максимальні частки в обсязі продажів у порівнянні 3 іншими видами продукції, що випускається [9]. В свою чергу Стрікленд і Томпсон проводять систематизацію видів диверсифікації, виділяючи такі стратегії диверсифікації: впровадження в нові галузі; придбання, створення нової компанії i спільного підприємства; споріднену диверсифікацію; неспоріднену диверсифікацію; виключення і ліквідацію; оновлення компанії, скорочення i реструктуризацію; багатонаціональну диверсифікацію [10].

Слід зауважити, що наведені дослідження диверсифікації проводилися на мікрорівні (на рівні підприємств і галузей). Рівень регіону або мезорівень стосовно питань диверсифікації висвітлено у працях вітчизняних дослідників.

Так, Снігова О. наголошує на необхідності розробки стратегії диверсифікації економіки старопромислових регіонів, яка повинна передбачати вибір оптимальних напрямів підвищення їх конкурентоспроможності в світовому економічному просторі [11].

Шпак А. у своїх працях визначає поняття «диверсифікація регіону», виокремлює іiі складові, а також пропонує пріоритетні напрямки диверсифікації регіональної економіки. При цьому наголошує, що ефективність реалізації стратегії диверсифікації економіки регіону знаходиться у прямій залежності від особливостей державної регіональної політики [12].

У дослідженнях Прушківської $\mathrm{E}$. i Куценко В. на основі порівняльного аналізу галузевої структури регіонів України в докризовий і післякризовий періоди здійснено спробу виокремити особливості диверсифікації економіки регіонів на основі індексу галузевої концентрації, що створить підгрунтя для сталого розвитку регіонів за рахунок більш раціонального використання природноресурсного потенціалу [13].

Мета статті (постановка завдання). Враховуючи вищенаведене, в якості основної мети статті $\epsilon$ визначення основних напрямів стратегіï розвитку регіонів в умовах диверсифікації галузевого профілю економіки.

Для досягнення зазначеної мети доцільно визначити галузевий профіль регіонів та виокремити проблеми монофункціональних територій (мономіст), провести статистичний аналіз міжрегіональних розбіжностей, на чого якого представляється можливим ідентифікувати варіанти диверсифікації.

Виклад основного матеріалу. Соціально-економічний розвиток країни, насамперед, залежить від стану базових галузей промисловості, при чому у випадку вузькоспеціалізованого розвитку виникає проблема залежності бюджету регіону від функціонування одного підприємства. Перехід до багатопрофільної діяльності дозволяє 
підвищити ефективність і стійкість економіки і покращити стан навколишнього середовища, завдяки чому диверсифіковані в економічному плані регіони в цілому виявляються більш стійкими, конкурентоспроможними порівняно 3 вузькоспеціалізованими.

Виходячи 3 цього головною метою диверсифікації економіки регіону є перехід від моноцентричної до поліцентричної іï структури.

Для більшої наочності представляється доцільним розглянути галузевий профіль економіки на прикладі Донецького регіону у формі табл. 1.1.

Таблиця 1 - Спеціалізація промисловості Донецького регіону

\begin{tabular}{|c|c|c|}
\hline Міста & $\begin{array}{c}\text { Базові галузі } \\
\text { промисловості }\end{array}$ & Основні підприємства \\
\hline Авдіївка & Коксохімічна & $\begin{array}{c}\text { ПрАТ «Авдіївський коксохімічний завод», ПрАТ «Авдіївський завод } \\
\text { металевих конструкцій» }\end{array}$ \\
\hline Бахмут & $\begin{array}{l}\text { Харчова та } \\
\text { переробна }\end{array}$ & $\begin{array}{c}\text { ТОВ «Завод кольорових металів», ПрАТ «ФІТОФАРМ», } \\
\text { ПрАТ «АРТВАЙНЕРІ», ТДВ «СІНІАТ», ПрАТ «Машинобудівний завод } \\
\text { «ВІСТЕК», ТОВ «БАХМУТ-ХЛІБ» } 12 \text { підприємств, з них три } \\
\text { підприємства харчової та переробної промисловості }\end{array}$ \\
\hline Вугледар & Вугледобувна & $\begin{array}{c}\text { ДП «Шахтоуправління «Південнодонбаське № 1» та ДП «Шахта ім. } \\
\text { М. С. Сургая» }\end{array}$ \\
\hline Добропілля & обувна & $\begin{array}{c}\text { шість вугільних підприємств, п’ять із яких входить до складу ТОВ «ДТЕК } \\
\text { Добропіллявугілля» та ТДВ «Шахта «Білозерська» }\end{array}$ \\
\hline Дружківка & $\begin{array}{l}\text { Машинобудівна, } \\
\text { добувна, харчова }\end{array}$ & $\begin{array}{c}\text { ТОВ «Корум Дружківський машинобудівний завод», } \\
\text { ПрАТ «Дружківський завод металевих виробів, ПрАТ «Грета», } \\
\text { ПрАТ «Веско», ПрАТ «Дружківське рудоуправління», } \\
\text { ТОВ «Дружківський вогнетривкий завод», ТОВ «Дружківський хліб» }\end{array}$ \\
\hline $\begin{array}{l}\text { Костянти- } \\
\text { нівка }\end{array}$ & $\begin{array}{l}\text { Металургійна, } \\
\text { машинобудівна, } \\
\text { легка, харчова }\end{array}$ & $\begin{array}{c}\text { ТОВ «Мегатекс», ТОВ «Спеціалізоване підприємство «Свинець», ПрАТ } \\
\text { «Цинк», ТОВ «Костянтинівський завод металургійного обладнання», } \\
\text { КДНВП «Кварсит», ТОВ «Гласкомерц», ПАТ «Завод обважнювачів», ПАТ } \\
\text { «Спецтехскло А», ТОВ «Шкіркон», ТОВ «НАК», ТОВ «Еталон-Плюс», } \\
\text { Костянтинівська кондитерська фабрика АТ ВО «КОНТІ» } \\
\end{array}$ \\
\hline $\begin{array}{l}\text { Краматор- } \\
\text { ськ }\end{array}$ & $\begin{array}{l}\text { Машинобудівна, } \\
\text { металургійна, } \\
\text { харчова та } \\
\text { переробна } \\
\end{array}$ & $\begin{array}{c}\text { ПрАТ «НКМЗ», ПАТ «ЕМСС», ПАТ «КЗВВ», } \\
\text { ТОВ «Фурлендервіндтехнолоджі», ТОВ «Краматорський комбінат } \\
\text { дитячого харчування» }\end{array}$ \\
\hline Map & $\begin{array}{l}\text { Металургійна, } \\
\text { машинобудівна }\end{array}$ & $\begin{array}{c}\text { Маріупольський морський торговельний порт, ММК ім. Ілліча, Азовський } \\
\text { судноремонтний завод, Магма, Азовсталь, Азовінтекс, Азовмаш, } \\
\text { Метінвест-Промсервіс, Сателлит }\end{array}$ \\
\hline Мир & $\begin{array}{l}\text { Вугледобувна, } \\
\text { машинобудівна }\end{array}$ & $\begin{array}{c}\text { Відокремлені підрозділи ДП «Мирноградвугілля»: шахта «Центральна», } \\
\text { шахта «5/6», шахта «Капітальна»; ТОВ «Вуглепромтранс»; ПрАТ ЦЗФ } \\
\text { «Мирноградська»; ТОВ «Димитровський експериментально-механічний } \\
\text { завод» }\end{array}$ \\
\hline $\begin{array}{l}\text { Новогро- } \\
\text { дівка }\end{array}$ & Вугледобувна & $\begin{array}{c}\text { ВП «Шахта 1/3 «Новогродівська», ВП «Шахта «Котляревська» } \\
\text { ДП «Селидіввугілля» }\end{array}$ \\
\hline Покровськ & $\begin{array}{l}\text { Вугледобувна, } \\
\text { машинобудівна, } \\
\text { металургійна }\end{array}$ & $\begin{array}{c}\text { ПрАТ «Шахтоуправління «Покровське», ВП «Шахта «Родинська» } \\
\text { ДП «Покровськвугілля», ДП «ВК «Краснолиманська», ПАТ «КДЗ», } \\
\text { Покровський динасовий завод, ТОВ «Покровський електромеханічний } \\
\text { завод», ПрАТ «Покровський машинобудівний завод», ТОВ «Покровський } \\
\text { завод залізобетонних виробів» }\end{array}$ \\
\hline Селидове & Вугледобувна & ВП «Шахта «Курахівська» та ВП «Шахта «Україна» ДП «Селидіввугілля» \\
\hline $\begin{array}{l}\text { Слов’ян- } \\
\text { ськ }\end{array}$ & $\begin{array}{l}\text { Машинобудівна, } \\
\text { переробна, } \\
\text { харчова }\end{array}$ & $\begin{array}{c}\text { ПАТ «Бетонмаш», ПАТ «Слов’янський машинобудівний завод», } \\
\text { ПрАТ «Кераммаш», ПрАТ «КБ Коксохіммаш», ПАТ «Зевс- Кераміка», } \\
\text { ТОВ «Керамічні маси Донбасу», ТОВ «СІС» Сода», ПрАТ «Хліб», } \\
\text { ПП «Істочнік», ПП «Слов’янська кондитерська фабрика «Валенсія» }\end{array}$ \\
\hline Торецьк & $\begin{array}{c}\text { Вугледобувна, } \\
\text { хімічна, харчова }\end{array}$ & $\begin{array}{c}\text { ДП «Торецьквугілля», ПАТ «Центральна збагачувальна фабрика } \\
\text { «Дзержинська», ТОВ «Науково-виробниче об’єднання «Інкор і К», ПАТ } \\
\text { «Торецький хлібокомбінат» }\end{array}$ \\
\hline
\end{tabular}

Складено автором за [14; 15] 
Дані табл. 1.1 свідчать, що для Донецького регіону є характерним наявність монофункціональних міст - мономіст. Мономіста - муніципальні утворення, у розвитку яких значну роль відіграють містоутворюючі підприємства, на яких або працює не менше $25 \%$ економічно активного населення міста, або виробляється не менше половини валового продукту міста [16]. Наприклад, в Авдіївці ПрАТ «Авдіївський косохімічний завод» займає більше 99\% в структурі випуску промисловості міста; в Краматорську машинобудівна галузь займає майже $\quad 80 \%$ у галузевій структурі промисловості; у Вугледарі, Мирнограді, Новогродівці, Селидовому на вугледобувну промисловість приходиться від 70 до 90\% загальних обсягів випуску промислової продукції [14].

Монофункціональність промисловості Донецького регіону призводить до виникнення проблем у соціальній сфері, особливо гостро це відсувається у містах 3 вугільною моноспеціалізацією. Головними причинами неефективного функціонування вугільної промисловості $€$ недостатня гнучкість і здатність до мобільної реструктуризації та реформування в стратегічному розвитку регіону; несприятливий інвестиційний клімат на фоні світової і локальної економічної кризи; відсутність науково обгрунтованої стратегії галузевого розвитку, яка передбачає оптимальний перехід від використання всіх енергоресурсів і спрямована на залучення інвестицій у розвиток вугільної промисловості.

Слід зауважити, що вугільна промисловість Донецької області характеризується видобутком у складних гірничо-геологічних умовах, які спричиняють високі витрати i значне коливання техніко-економічних показників вугільних підприємств. Промислововиробничі фонди деяких вуглевидобувних підприємств зношені в середньому на $65 \%$. Переважна більшість вуглевидобувних підприємств є збитковими i потребують систематичної значної фінансової підтримки [15].

Якщо моногалузеве місто обмежене у розвитку виробництвом i попитом, то багатогалузева (диверсифікована) економіка має додаткові можливості для свого розвитку і підвищення ефективності виробництва.

При проведенні аналізу регіональних диверсифікаційних процесів головну увагу слід приділяти їх ринковим аспектам. Маркетинговий аналіз економіки міста обгрунтовує стратегію диверсифікації 3 позиції посилення ринкових сил. Міста регіону стануть спроможними уникати коливань ринкової кон'юнктури лише в тому випадку, якщо матимуть декілька напрямків економічної діяльності, яким властиві різні ризикові характеристики.

Таким чином, мотиваційними чинниками диверсифікації регіональної економіки є: зменшення операційних ринкових витрат, збільшення ефективності внутрішнього використання ресурсів, створення ефективної внутрішньої системи капіталовкладень і грошових потоків.

Процесам планування і прогнозування зростання обсягів виробництв диверсифікованої економіки регіону повинно передувати проведення детального аналізу регіональних ресурсів, а також визначення структуроутворюючого центру.

Виходячи 3 цього, під стратегією диверсифікації регіональної економіки розуміється розвиток в регіоні галузей, пов'язаних 3 профільною діяльністю структуроутворюючого центру, що представляє собою домінуючу галузь або групу галузей, в яких регіон має конкурентні переваги [17].

В якості головних цілей диверсифікації економіки регіону, а також суб'єктів господарювання виступають: підвищення конкурентоспроможності регіону; зниження ризиків бізнесу; підвищення рентабельності; зростання компаній регіону. Разом 3 цим на шляху диверсифікації економіки Донецького регіону виникають суттєві бар'єри, пов'язані в першу чергу з концентрацією певного виду економічної діяльності в мономістах, яка $є$ наслідком глибоких міжрегіональних розбіжностей в їх економічному розвитку. Одним із способів подолання концентрації $\epsilon$ інтеграція (поєднання та виникнення нових економічних зв'язків). Крім того, процеси концентрації і інтеграції приводять до появи спільних ознак - конвергенції, завдяки якій відбувається зменшення міжрегіональних розбіжностей. Взаємозв'язок між розбіжностями i зазначеними процесами наведено в табл. 1.2. 
Таблиця 1.2 - Взаємозв'язок процесів розвитку економіки регіону і міжрегіональних розбіжностей

\begin{tabular}{|l|c|c|c|}
\hline Тенденції міжрегіональних розбіжностей & Концентрація & Інтеграція & Конвергенція \\
\cline { 2 - 4 } в розвитку економіки регіону & Деконцентрація & Дезінтеграція & Дивергенція \\
\hline Міжрегіональні розбіжності зростають & + & & \\
\cline { 2 - 4 } & & + & + \\
\hline Міжрегіональні розбіжності зменшуються & & + & + \\
\cline { 2 - 4 } & + & & + \\
\hline
\end{tabular}

Джерело: [18]

Отже, внаслідок зростання міжрегіональних розбіжностей в економічному розвитку регіону маються місце процеси концентрації, дезінтеграції і деконвергенції, що ускладнює реалізацію стратегії диверсифікації. I, навпаки, звуження розбіжностей прискорює процеси диверсифікації через деконцентрацію, інтеграцію і конвергенцію.

Аналіз міжрегіональних розбіжностей представляється доцільним здійснити а допомогою коефіцієнту варіації (v), що характеризує коливання значень показника в системі регіонів навколо їх середнього значення (спільного для всієї системи регіонів):

$$
V=\frac{\sigma}{\bar{X}} * 100 \%,
$$

де $\sigma \quad-$ середньоквадратичне відхилення;

$\bar{X}$ - середнє значення показника за всіма досліджуваними територіями.

Якщо значення коефіцієнту варіації знаходяться в межах від 0 до $10 \%$, то рівень розбіжностей у межах норми; від 10 до 20\%

- рівень розбіжностей у зоні потенційної небезпеки; від 20 до $40 \%$ - рівень розбіжностей у зоні безпосередньої небезпеки; понад $40 \%$ - рівень розбіжностей у зоні реальної небезпеки.

В якості бази для проведення аналізу тенденції міжрегіональних розбіжностей Донецького регіону обрано показник валової доданої вартості (ВДС) (табл. 1.3).

Таблиця 1.3 - Динаміка валової доданої вартості Донецького регіону у 2014-2018 рр., млн. грн.

\begin{tabular}{|l|c|c|c|c|c|}
\hline \multicolumn{1}{|c|}{ Міста } & 2014 & 2015 & 2016 & 2017 & 2018 \\
\hline Авдіївка & 3430,558 & 4418,791 & 6091,527 & 12409,95 & 15128,13 \\
\hline Бахмут & 2737,969 & 2745,751 & 1461,725 & 1620,335 & 1806,976 \\
\hline Вугледар & 353,1553 & 390,7999 & 347,6171 & 386,4927 & 535,1302 \\
\hline Добропілля & 1302,24 & 1706,479 & 1369,656 & 2004,738 & 2968,648 \\
\hline Дружківка & 1605,775 & 2108,163 & 2247,439 & 3233,855 & 3540,055 \\
\hline Костянтинівка & 1120,283 & 1697,897 & 2576,088 & 2954,704 & 2984,627 \\
\hline Краматорськ & 3256,285 & 3006,982 & 10606,86 & 10863,23 & 12625,03 \\
\hline Маріуполь & 30499,74 & 33105,16 & 38326,26 & 59045,59 & 73209,9 \\
\hline Мирноград & 284,7088 & 239,5664 & 1328,645 & 1260,006 & 1285,522 \\
\hline Новогродівка & 243,2128 & 392,7361 & н/д & н/д & 107,7746 \\
\hline Покровськ & 2115,09 & 2043,902 & 2477,765 & 4498,039 & 11272,95 \\
\hline Селидове & 102,2032 & 226,2223 & 238,4261 & 338,0941 & 269,1966 \\
\hline Слов’янськ & 1337,094 & 1652,003 & 838,2591 & 942,1568 & 1183,697 \\
\hline Торецьк & 380,5449 & 339,1502 & 417,848 & 538,8017 & 722,2722 \\
\hline Коефіціснт варіації $(V), \%$ & 217,33 & 212,25 & 189,09 & 198,50 & 202,01 \\
\hline
\end{tabular}

Розраховано автором за [14]

Оцінка отриманих значень коефіцієнту варіації показника ВДС свідчить про наявність глибоких міжрегіональних розбіжностей, які знаходяться в зоні реальної небезпеки. Таким чином, важливим напрямом економічного розвитку регіону має стати саме стратегія диверсифікації шляхом інтеграції і конвергенції. При чому вид та етапи диверсифікації будуть залежати від конкретних умов господарювання, проте більшу увагу варто приділити розвитку інноваційних галузей економіки. 
Обговорення результатів. За результатами теоретичного дослідження питань диверсифікації представляється доцільним стверджувати про ефективність даного напряму розвитку економіки регіону в умовах високої концентрації і наявності глибоких міжрегіональних розбіжностей.

Досвід вказує на те, що диверсифіковані в економічному плані міста менш вразливі до наслідків економічних та галузевих криз. Інакше кажучи, диверсифікація $\epsilon$ найкращим шляхом досягнення стійкості економіки мономіст.

Використання запропонованої стратегії диверсифікації знайшло позитивне відображення в зарубіжній практиці регіонального розвитку. Так, ще $з$ середини минулого століття більшість розвинених країн світу пройшли шлях від держав 3 первинним сектором економіки до держав високого рівня розвитку, внаслідок чого їх економічні показники зросли майже вдвічі.

Практичне значення запропонованого стратегічного напряму розвитку регіональної економіки полягає у посиленні ролі інших галузей, крім тієї, яка є основною для конкретного регіону, i зменшенні залежності економіки міста від функціонування містоутворюючих підприємств, що створить підгрунтя для

\section{Список літератури}

1. Алимова Т. Диверсификация деятельности малых предприятий. Bonpocbl экономики. 2007. № 6. С. 17-23.

2. Andrews K. The Concept of Corporate Strategy. Homewood: Homewood University Press, 1971. 498 p.

3. Gort M. Diversification and integration in American industry. Prinston: Prinston University Press, 1962. 508 p.

4. Berry C.H. Corporate Growth and Diversification. Journal of Law and Economics. 1971. Vol. 14. № 2. P. 371-383.

5. Yoshinara E., Sakuma A., Itami K. Diversification strategy in Japanese company. Tokyo, Nipon Keirai, 1979. 434 p.

6. Rumelt R.P. Strategy, structure and economic performance. Boston, 1974.

7. Ансофф И. Стратегический менеджмент. Санкт-Петербург: Питер, 2009. 344 с.

8. Котлер Ф., Келлер К. Маркетинг менеджмент. Санкт-Петербург: Питер, 2012. $480 \mathrm{c}$. подальшого соціально-економічного благополуччя таких територій.

Висновок. Розвиток економіки регіону шляхом диверсифікації потребує підтримки, зокрема фінансової, нових сфер діяльності. Реалізація регіональних програм в більшості випадків обмежується контролем за термінами i іноді якістю виконання окремих заходів, в той час як їх вплив на конкурентоспроможність економіки регіону не оцінюється. Для розвитку регіональної економіки доцільно проводити грунтовний аналіз соціальноекономічного положення регіону, що дасть можливість обрати галузевий профіль майбутнього. При цьому органам регіональної влади, які прагнуть підвищити регіональну конкурентоспроможність, важливо заохочувати зміни і стимулювати інновації.

Перспективи проведених досліджень полягають у тому, що вони можуть бути використані в процесі обгрунтування та прийняття рішень щодо удосконалення системи регіонального соціальноекономічного розвитку, а також є підгрунтям для оптимізації регіонального господарювання та зростання добробуту населення.

9. Портер М. Конкурентная стратегия. Методика анализа отраслей и конкурентов. Москва: Альпина Паблишер, 2017. 454 с.

10. Томпсон А.А., Стрикленд А.Дж. Стратегический менеджмент. Искусство разработки и реализации стратегии. Москва: Банки и биржи: ЮНИТИ, 1998. 576с.

11. Снігова О.Ю. Еволюція підходів до диверсифікації економіки в дослідженнях регіонального розвитку. Вісник соціальноекономічних досліджень: зб. наук. пращь. Одеса: Одеський національний економічний університет. 2019. № 1 (69). С. 83-95.

12. Шпак А.Д. Диверсифікація регіонів: сутність, причини та наслідки виникнення. Економічний аналіз: зб. наук. прац̧ь Тернопільського національного економічного університету. 2015. Том 21. № 1. С. 139-145.

13. Прушківська Е.В., Куценко В.І. Аналіз диверсифікації галузевої структури економіки регіону в до кризовий та посткризовий періоди. Бізнес Інформ. 2015. № 1. С. 91-96.

14. Офіційний сайт Головного управління статистики у Донецькій області. URL: 
http://www.donetskstat.gov.ua/ (дата звернення: 17.11.2019).

15. Стратегія розвитку Донецької області на період до 2027 року: проект. 2019. 218 с.

16. Иванова С.А. Современные проблемы и тенденции социально-экономического развития малых и моногородов. Устойчивое развитие экономики территорий на основе сетевого взаимодействия мальх городов и сельских поселений. Москва: Экономический факультет МГУ, 2018. С. 22-32.

17. Севастьянова А.Е., Шмат В.В. Ситуационный анализ диверсификации экономики нефтегазодобы-вающего региона. Регион: экономика и соціологія. 2006. № 2. C. 49-66.

18. Науково-методичні рекомендації по діагностиці міжрегіональних розбіжностей у економічному розвитку регіонів: проект. Донецьк: Ін-т екон.-прав. дослідж. НАН України, 2011. 16 с.

\section{References}

1. Alimova, T. (2007). Diversification of small enterprises. Issues of economics, 6, 17-23. [in Russian].

2. Andrews, K. (1971). The Concept of Corporate Strategy. Homewood: Homewood University Press, 498. [in English].

3. Gort, M. (1962). Diversification and integration in American industry. Prinston: Prinston University Press, 508. [in English].

4. Berry, C.H. (1971). Corporate Growth and Diversification. Journal of Law and Economics, 14, 2, 371-383. . [in English].

5. Yoshinara, E., Sakuma, A., Itami, K. (1979). Diversification strategy in Japanese company. Tokyo, Nipon Keirai, 434. [in English].

6. Rumelt, R.P. (1974). Strategy, structure and economic performance. Boston, [in English].

7. Ansoff, I. (2009). Strategic management. St. Petersburg: Peter, 344. [in Russian].

8. Kotler, F., Keller, K. (2012). Marketing Management. St. Petersburg: Peter, 480. [in Russian].

9. Porter, M. (2017). Competitive strategy. Methods of analysis of industries and competitors.
Moscow: Alpina Publisher, 454. [in Russian].

10. Thompson, A.A., Strickland, A.J. (1998). Strategic management. The art of strategy development and implementation. Moscow: Banks and Exchanges: UNITI, 576. [in Russian].

11. Snigova, O.Yu. (2019). Evolution of approaches to economic diversification in regional development research. Bulletin of socio-economic research: coll. Science. wash. Odessa: Odessa National Economic University, 1 (69), 83-95. [in Ukrainaian].

12. Shpack, A.D. (2015). Diversification of regions: essence, causes and consequences. Economic analysis: Coll. Science. Proceedings of Ternopil National Economic University, 21, 1, 139-145. [in Ukrainaian].

13. Prushkivska, E.V., Kutsenko, V.I. (2015). Analysis of the diversification of the sectoral structure of the region's economy in the pre-crisis and post-crisis periods. Business Inform, 1, 9196. [in Ukrainaian].

14. Official site of the Main Department of Statistics in Donetsk region. [online]. Retrieved from: http://www.donetskstat.gov.ua/. [in Ukrainaian].

15. Development strategy of Donetsk region for the period up to 2027: project. (2019). 218. [in Ukrainaian].

16. Ivanova, S.A. (2018). Modern problems and trends in the socio-economic development of small and single-industry towns. Sustainable development of the economy of the territories on the basis of network interaction of small towns and rural settlements. Moscow: Faculty of Economics, Moscow State University, 22-32. [in Russian].

17. Sevastyanova, A.E., Shmat, V.V. (2006). Situational analysis of diversification of the economy of the oil and gas region. Region: economics and sociology, 2, 49-66. [in Russian].

18. Scientific and methodical recommendations for the diagnosis of interregional differences in the economic development of regions: a project. (2011). Donetsk: Inst. Of Economics and Law research. NAS of Ukraine, 16. [in Ukrainaian].

\section{Надійшла до редакиії 10.12.2019 p.}

Василишина Любов Миколаївна - старший викладач, ДВНЗ «Донецький національний технічний університет», кафедра управління і фінансово-економічної безпеки, м. Покровськ.

E-mail: liubov.vasylyshyna@donntu.edu.ua 


\section{STRATEGY OF REGIONAL DEVELOPMENT IN CONDITIONS OF ECONOMIC DIVERSIFICATION}

Substantiation of theoretical and methodological principles and practical recommendations for determining the main directions of the strategy of regional development in terms of diversification of the sectoral profile of the economy. Methodology. Theoretical and practical research of diversification is carried out on the basis of generalization, analysis and synthesis. The method of structural logical analysis was used to determine the sectoral profile of the economy of the Donetsk region. The establishment of interregional differences was carried out using the statistical method and the method of formalization. Results. It is emphasized that the most successful strategy is the strategy of diversification, as a result of which the risks of cyclical development of the regional economic system related to the situation, specific resources, geopolitical, infrastructural conditions of the socio-economic system of the region are dispersed. It is substantiated that the diversified economy has additional opportunities for its development and increase of production efficiency. The sectoral profile of the economy of the Donetsk region is analyzed and the problems related to the mono-functionality of cities are revealed. The presence of deep interregional differences in terms of gross value added, which are in the zone of real danger, has been established. According to the results of the study, it is substantiated that an important direction of economic development of the region should be the strategy of diversification through integration and convergence. The peculiarities of diversification will depend on the specific economic conditions, however, it is emphasized that more attention should be paid to the development of innovative sectors of the economy. Scientific novelty. Deepening of theoretical bases, scientific and methodical approaches and practical tools for determining the main directions of regional development strategy in terms of diversification of the sectoral profile of the economy in conditions of deep interregional differences. Practical significance. Strengthening the role of industries other than the main one for a particular region, and reducing the dependence of the city's economy on the functioning of city-forming enterprises, which will create the basis for further socio-economic well-being of such areas.

Keywords: region, development strategy, economic diversification, single city, monofunctionality, regional differences, concentration, integration, convergence

Vasylyshyna Liubov - Senior lecturer, Donetsk national technical university, Department of Management and Financial and Economic Security, Pokrovsk

E-mail: liubov.vasylyshyna@donntu.edu.ua

\section{СТРАТЕГИЯ РАЗВИТИЯ РЕГИОНОВ В УСЛОВИЯХ ДИВЕРСИФИКАЦИИ ЭКОНОМИКИ}

Обоснование теоретико-методических основ и практических рекомендаций по определению основных направлений стратегии развития регионов в условиях диверсификации отраслевого профиля экономики. Методика. Теоретическое и практическое исследование вопросов диверсификации осуществлено на основе обобщения, анализа и синтеза. Для определения отраслевого профиля экономики Донеикого региона использован метод структурно логического анализа. Установление межрегиональных различий осуществлено с помощью статистического метода и метода формализации. Результаты. Акиентировано внимание, что наиболее успешной стратегией является стратегия диверсификации, в результате чего достигается рассредоточение рисков цикличности развития региональной экономической системы, связанных с конъюнктурой, специфическими ресурсами, геополитическими, инфраструктурными условиями функционирования сочииально-экономической системы региона. Обосновано, что диверсифицированная экономика имеет дополнительные возможности для своего развития и повышения эффективности производства. Проанализирован отраслевой профиль экономики Донеикого региона и выявлены проблемы, связанные с монофункциональностью городов. Установлено наличие глубоких межрегиональных различий по показателю валовой добавленной стоимости, которые находятся в зоне реальной опасности. По результатам исследования обосновано, что важным направлением экономического развития региона должна стать именно стратегия диверсификации путем интеграции и конвергенџии. Особенности диверсификации будут зависеть от конкретных условий хозяйствования, однако, акцентировано, что большее внимание стоит уделить развитию инновационных отраслей экономики. Научная новизна. Углубление теоретических основ, научно-методических подходов и практического инструментария по определению основных направлений стратегии развития регионов в условиях диверсификации отраслевого профиля экономики в условиях глубоких межрегиональных различий. Практическая значимость. Усиление роли других отраслей, кроме той, которая является основной для конкретного региона, и уменьшение зависимости экономики города от функционирования градообразующих предприятий, создаст основу для дальнейшего социально-экономического благополучия таких 
территорий.

Ключевые слова: регион, стратегия развития, диверсификация экономики, моногород, монофункциональность, региональные различия, концентрация, интеграция, конвергенции

Василишина Л.Н. - старший преподаватель, Донецкий национальный технический университет, кафедра управления и финансово-экономической безопасности, г. Покровск

E-mail: liubov.vasylyshyna@donntu.edu.ua 